\title{
Implications of Papyrus (Cyperus papyrus L.) Biomass Harvesting on Nutrient Regulation in Nyando Floodplain Wetland, Lake Victoria, Kenya
}

\author{
P. J. K. Rongoei ${ }^{1}$ C , S. T. Kariuki ${ }^{2}$ \\ ${ }^{1}$ Department of Environmental Sciences, Egerton University, Njoro, Kenya \\ ${ }^{2}$ Department of Biological Sciences, Egerton University, Njoro, Kenya \\ Email: priscah.rongoei@gmail.com
}

How to cite this paper: Rongoei, P.J.K. and Kariuki, S.T. (2019) Implications of Papyrus (Cyperus papyrus L.) Biomass Harvesting on Nutrient Regulation in Nyando Floodplain Wetland, Lake Victoria, Kenya. Open Journal of Ecology, 9, 443-457.

https://doi.org/10.4236/oje.2019.910029

Received: July 26, 2019

Accepted: October 12, 2019

Published: October 15, 2019

Copyright $\odot 2019$ by author(s) and Scientific Research Publishing Inc. This work is licensed under the Creative Commons Attribution International License (CC BY 4.0).

http://creativecommons.org/licenses/by/4.0/

\begin{abstract}
Harvesting of papyrus biomass plays a significant role in regulating ecosystem services of which one of them is nutrient uptake and cycling. Despite Lake Victoria's wetlands being important, little is understood about its role in nutrient uptake and removal. Although there have been studies done in these wetlands, there is inadequate understanding on the implication of unselective biomass harvesting on the water quality of Lake Vitoria. At the same time, these wetlands are threatened by livelihood-related pressures which are driven by extreme hydrological regimes. This study focused on Nyando floodplain wetland located in the Eastern part of the shores of Lake Victoria which is a lifeline to many rural communities living around the lake. Papyrus biomass harvesting was assessed in two study sites of Nyando wetland and at different seasons in order to determine its implication on nutrient regulating services. Participatory tools, field survey, observation, field measurements and laboratory analysis were used. Harvesting of papyrus removed $530.6 \mathrm{Kg}$ $\mathrm{N} / \mathrm{g} \mathrm{DM} / \mathrm{ha} /$ day and $97 \mathrm{Kg} \mathrm{P} / \mathrm{g} \mathrm{DM} /$ ha/day in Ogenya while $771.2 \mathrm{Kg} \mathrm{N} / \mathrm{g}$ $\mathrm{DM} / \mathrm{ha} /$ day and $109.2 \mathrm{Kg} \mathrm{P} / \mathrm{g} \mathrm{DM} /$ ha/day were removed in Wasare. However, addition of nutrients to the wetland may lead to the problem of eutrophication especially at the site where interaction of wetland and lake water occurs. Understanding the role of papyrus harvesting patterns is crucial for better planning and management of this complex resource in a changing environment.
\end{abstract}

\section{Keywords}

Papyrus Biomass, Growth Stages, Nutrients, Nyando Wetland, Lake Victoria 


\section{Introduction}

Wetlands are important in provisioning and regulating ecosystem services which make an enormous contribution to the livelihoods of millions of people in Sub-Saharan Africa. According to [1] and [2] ecosystem services are the benefits people obtain from ecosystems. These include provisioning, regulating, cultural and supporting services. Provisioning services are the products obtained from ecosystems and include food, water, fuel and other materials while regulating services are benefits obtained from regulation of ecosystem processes. These include water purification, water regulation, climate, and flood control. African wetland areas have supported directly and indirectly livelihoods of millions of the rural poor through provisioning services. Apart from provisioning fertile soil and water for crop cultivation, these wetlands provide plants that are harvested by the communities for making mats, thatching and other artefacts.

Papyrus wetlands at the shores of Lake Victoria play an important role in taking up excess nutrients and filtering run off sediments carried from catchment areas hence purifying and preventing eutrophication [3] [4] [5]. When papyrus plants are harvested, they lead to the removal of nutrients from the system [6]. This depends on the type of vegetation and the intensity of livelihood activities practiced in the ecosystem. By purifying water, it enables the rural population not only to get clean water but also get fish which is a source of protein and income. Nutrient uptake is determined by papyrus growth rate, density, and water depth in the wetland, including nutrient content and harvesting rates. It is important to understand these patterns as they assist in determining the harvesting patterns that will help in provisioning and regulating ecosystem services.

Despite the importance of these ecosystems and the services they provide to humans, wetlands have been threatened mainly by conversion to agriculture [1] [7]. Loss of wetlands has been exacerbated by the need to increase economic development, to meet food security and to reduce poverty for the growing population. More so, increasing climate variability has led to expansion of dry areas in the wetland that leads to more accessibility for various exploitation activities. Though increased conversion of wetlands to croplands and clear-cutting of natural vegetation endanger regulating services, there is need to understand these services and quantify them for decision-making. A balance between well-functioning ecosystem and maintaining the wellbeing of society has been a concern for environmental managers, decision-makers and planners.

Nyando floodplain wetland in the Eastern part of Lake Victoria is dominated by papyrus and is important in provisioning services that depend on the regulating services. According to [8] the major provisioning services in Nyando wetland include crop cultivation, livestock keeping and papyrus harvesting. Crop cultivation and livestock grazing is practised in the seasonally inundated zones of the wetland and raised parts of the floodplain while papyrus biomass is harvested from permanently inundated zones [9]. Harvested papyrus is used for mat-making, artefacts, construction and for income generation. 
The main aim of this study is to understand the implications of papyrus harvesting on nutrient regulating services in the face of human and natural-induced pressures. It is hypothesized that, harvesting of papyrus biomass may play a crucial role in regulating nutrients even in the face of unreliable rainfall patterns coupled with increasing human pressures than other vegetation. However, this depends on the harvesting rate, harvested area, growth stages, seasonality and nutrient content of the plant. To achieve this, the following specific objectives were formulated: 1) To determine the biomass productivity of different growth stages of papyrus in the study sites of the wetland; 2) To quantify the amount of nitrogen and phosphorus ( $\mathrm{N}$ and $\mathrm{P}$ ) in papyrus tissues at different growth stages in Nyando floodplain wetland (ii) To extrapolate the amount of nutrients removed by harvested papyrus and its implications on Lake Victoria ecosystem.

\section{Methodology}

\section{Study Area}

The study was conducted in Nyando floodplain wetland on the North Eastern shores of Lake Victoria, Kenya. The wetland is found at an interface between River Nyando and Lake Victoria. The wetland area is not clearly known but has been estimated to be 3000 to 5000 hectares [10] [11]. It stretches from the mouth of Nyando River at Nyakach bay extending from $0^{\circ} 11^{\prime}-0^{\circ} 19^{\prime} \mathrm{S}$ to $34^{\circ} 47^{\prime}-$ $34^{\circ} 57^{\prime} \mathrm{E}$ (Figure 1).

The annual rainfall received is between 1000 and $1600 \mathrm{~mm}$ with a mean of $1184 \mathrm{~mm}$ and an estimated mean temperature of $23^{\circ} \mathrm{C}$ [12]. The long rains are received between March and May while short rains in October and December.

The Luo community living around the wetland practices various socio-economic activities which include fishing, animal husbandry, mat-making, cultivation of crops among others.

\section{Study Approach}

An ecological survey was used as a tool to obtain the information required in the wetland. This was through the papyrus growth and its associated vegetation in the two study areas. The ecological survey as well as the experimental approach was used in order to obtain information on the standing biomass in each study site.

\subsection{Determination of Nutrient Content in C. papyrus Growth Stages in Nyando Floodplain Wetland}

Since harvesting of papyrus biomass was important in contributing to the livelihoods of the people, an experiment to determine the biomass and nutrient contents was done for the different growth stages of papyrus. Standing crop of papyrus plants were harvested once in the intact (relatively undisturbed by human activities) areas of the wetland in the three study sites of the wetland in the month of February 2011. Ten quadrats of $1 \mathrm{~m} \times 1 \mathrm{~m}$ were harvested in each site 


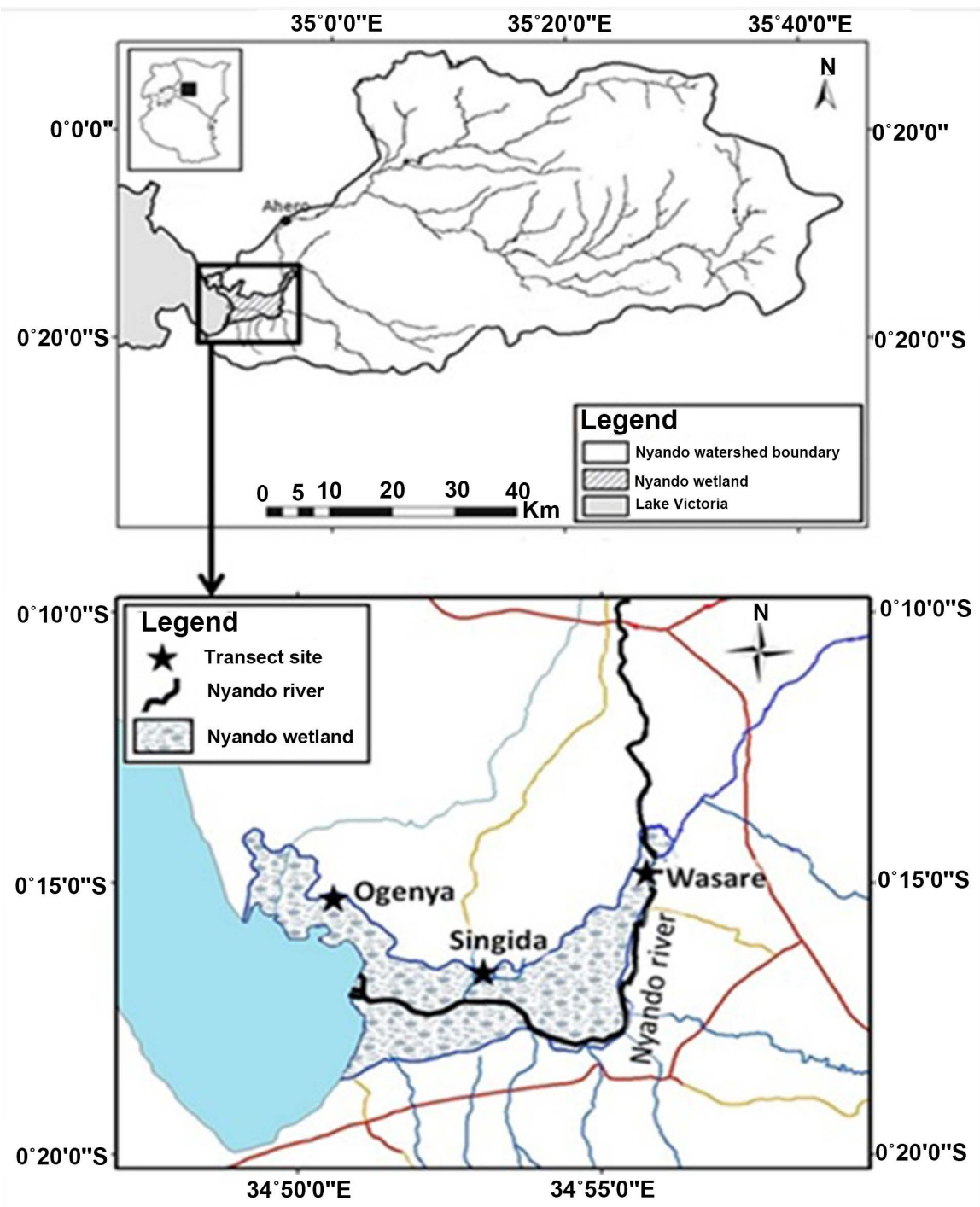

Figure 1. Location of Nyando wetland in relation to Lake Victoria showing the study sites.

and plants separated into growth stages as follows and modified from [13]; growth stage 1-closed umbel, growth stage 2-umbel just opening, growth stage 3-mature umbel, growth stage 4-flowering umbel, growth stage 5-senescing umbel and culm, and finally growth stage 6-dry umbel and culm (Figure 2). All other plants associated with papyrus found within the quadrat were also measured and named others. Associated plants were identified in the field. Those that were not able to be identified were collected in the field, pressed between two paper boards and transported to the botanical laboratory at Egerton University where they were identified.

Fresh biomass of each growth stage was measured in the field and a sub-sample of each was re-weighed, cut into small pieces and placed in labelled bags and transported to Egerton University, Department of Biological Sciences for processing. In the laboratory, the plant parts were further cut into smaller pieces $(\sim 2 \mathrm{~cm})$ and sundried for three days before they were placed in the oven 




Figure 2. C. papyrus plants showing different growth stages with their associated plants. The growth stage 5 senescing is not shown in the figure since it was not captured in the picture.

at $60^{\circ} \mathrm{C}$ for another $2-3$ days until a constant weight was obtained. The wet weight to dry ratio of the sub-sample was used to calculate the total above ground dry biomass and results presented in grams per meter square. This biomass was used to determine how much biomass can be harvested by people from the wetland area in each site.

Dry plant parts were finely ground using a mill and sieved through a $100 \mu \mathrm{m}$ sieve. To determine how much nutrients are stored in each growth stage, Kjeldahl method was used for nitrogen $(\mathrm{N})$ concentration while molybdate-ascorbic acid method was used to determine phosphorus $(\mathrm{P})$ following the standards for nutrient analysis [14]. The results were used to calculate how much nutrients are left in the wetland area and how much is transported away from the wetland by people. Dried parts of growth stage 1 and 2 were mixed to form growth stage named young stage as growth stage 1 had few samples and both stages were left to rot in the field by harvesters. At the same time growth stage 3 and 4 were mixed to form mature growth stage since both mature and flowering (4) were taken away from the field by harvesters. This was followed by senescing and dry growth stages as well as other plants associated with the papyrus.

The amount of nutrients in different growth stages was used to extrapolate the amount of nutrients that would be carried away from the wetland by the harvesters and that which remain in the field. Biomass of the growth stage multiplied by the nutrient concentration of that growth stage multiplied by the area harvested per day by individual harvesters was used to determine the amount of nutrients removed and that which remained in the system. The results would help in understanding the implications of random harvesting of papyrus on nutrients getting to Lake Victoria.

\subsection{Data Analysis}

Descriptive statistics that entailed mean, standard deviation was used in determining the biomass of the growth stages of papyrus in each study site. Normal distribution of collected data was done using Shapiro-Wilk test. For tests that met normal distribution, one way ANOVA was used to analyse the differences in 
nutrient content among growth stages of papyrus while Tukey HSD test was used for post-hoc test. Those that did not meet normal distribution test were then subjected to non-parametric analysis of variance (ANOVA) using Kruskal-Wallis Test. Kruskal-Wallis multiple comparison tests were used for post-hoc analysis. All tests were conducted at 5\% probability level unless otherwise stated. All analyses were done using R version 3.1.3 [15].

\section{Results}

\subsection{Above Ground Biomass of Different Papyrus Growth Stages}

Based on standing biomass measures taken from ten $1 \mathrm{~m}^{2}$ quadrats, papyrus biomass yield in Nyando wetland varied according to study sites. The overall mean aerial dry biomass was $4353 \pm 560 \mathrm{~g} / \mathrm{m}^{2}, 6486 \pm 606 \mathrm{~g} / \mathrm{m}^{2}$ and $3537 \pm 188$ $\mathrm{g} / \mathrm{m}^{2}$ in Wasare, Ogenya and Singida respectively. Based on the growth stages of papyrus determined in each study site, it shows that the young stage had the lowest biomass while the senescing growth stage had the highest biomass in all the sites (Figure 3).

Furthermore, the first growth stage (closed) had similar percentage biomass in all the sites. Just opening and mature growth stages dominated Singida site while flowering and senescing dominated Ogenya site (Figure 4).

One way ANOVA showed that there was variability in biomass among growth stages $(\mathrm{F}=10.91 ; \mathrm{P}<0.001)$. The percentage of above ground dry biomass of other plants associated with papyrus in the wetland was mainly from Singida followed by Ogenya and the least was in Wasare. Most of the associated plants

Papyrus biomass

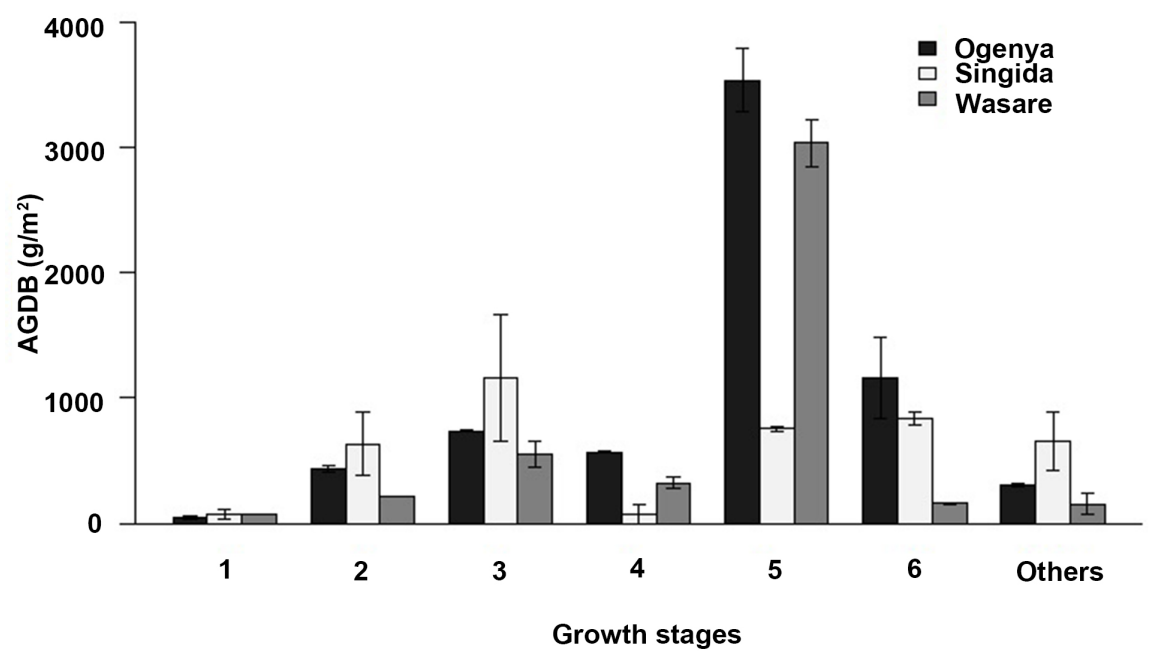

Figure 3. Above ground dry biomass distribution among the six growth stages of C. papyrus in the three study sites of Nyando floodplain wetland. Growth stages 1-closed, 2-just opening, 3-mature, 4-flowering, 5-senescing, 6-dry and others (papyrus associated plants such as I. aquatic, I. whightii and Cyphostema sp.) ( $\mathrm{n}=10$; the arrow bars depict mean \pm standard error of mean). 


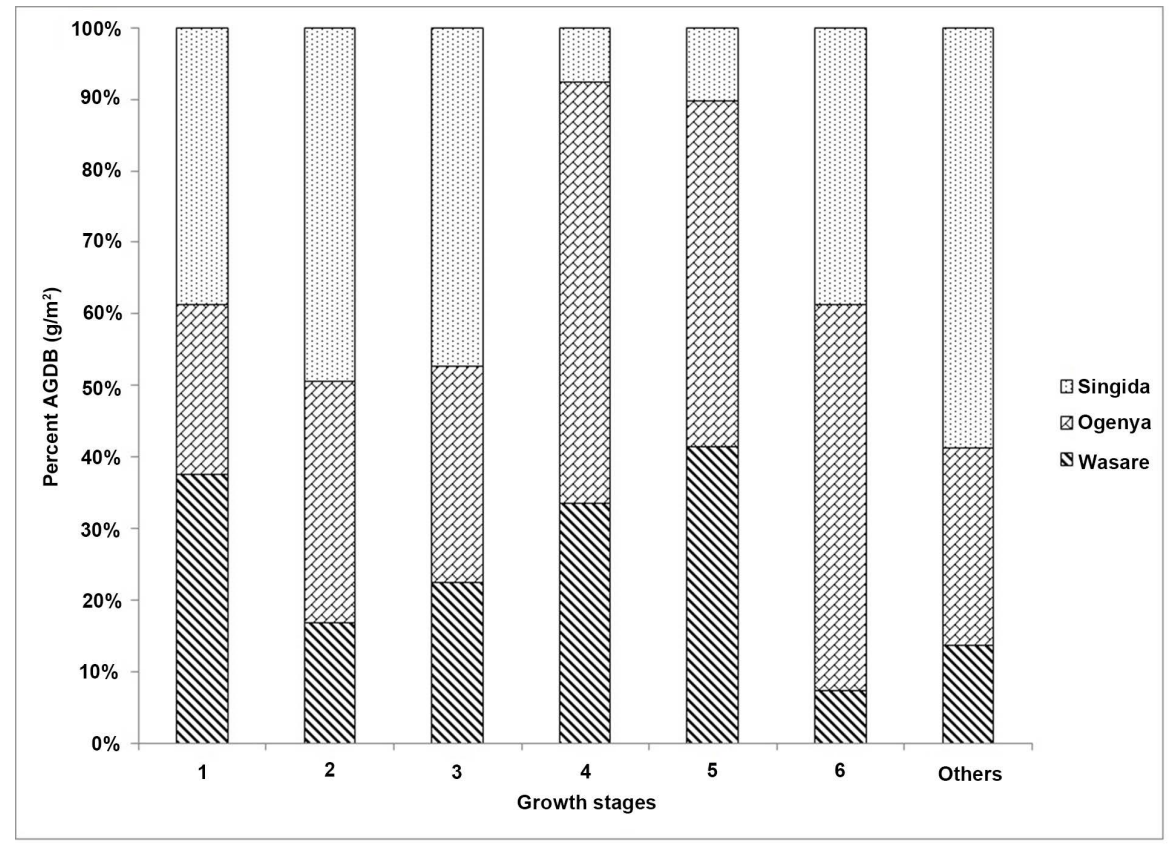

Figure 4. Percentage contribution of biomass by six growth stages of $C$. papyrus at the three study sites. Growth stages 1-closed, 2-just opening, 3-mature, 4-flowering, 5-senescing, 6-dry and others (associated plants where $I$. whightii dominated Singida, $I$. aquatic dominated Wasare and I. aquatic, Commelina dominated Ogenya).

were Vossia cuspidata which was common in all the three sites while Ipomoea aquatica and Ipomoea wrightii were common in Wasare and Singida, respectively. Other plants that were found in Wasare were Commelina sp., Cyphostemasp. and Polygonum sp. as described in [9].

\subsection{Nutrient Storage in Papyrus Plant Tissues}

Nitrogen and phosphorus in papyrus was high in young plants (1-closed and 2just opening) and decreased as the plant aged. Figure 5 depicts highest nitrogen content in the young growth stages $(1 \& 2)$ with a mean of $27.4 \pm 4.0,14.3 \pm 3.7$ and $29.6 \pm 0.8 \mathrm{mg} / \mathrm{g}$ in Singida, Ogenya and Wasare respectively. The least nitrogen was observed in dry growth stage of papyrus plant with a mean of $4.67 \pm$ $1.11,0.92 \pm 0.01$ and $3.96 \pm 0.13 \mathrm{mg} / \mathrm{g}$ in Singida, Ogenya and Wasare respectively (Figure 5(a)). Nitrogen stored in the plant tissues was significantly lower in Ogenya as compared to Singida transect $(\mathrm{F}=4.09 ; \mathrm{P}<0.05)$. This may be as a result of nutrients being washed into the lake by wave action and leaching into the interstitial areas as a result of daily rising and falling of water levels in the lake.

Similarly, phosphorus in papyrus tissues was relatively higher in young papyrus as compared with the mature, senescing and dry growth stages of papyrus (Figure 5(b)). Singida had the highest phosphorus stored in the young papyrus $(5.98 \pm 1.32 \mathrm{mg} / \mathrm{g})$, followed by Wasare with a mean of $5.38 \pm 0.15 \mathrm{mg} / \mathrm{g}$ while Ogenya had a mean of $2.98 \pm 0.90 \mathrm{mg} / \mathrm{g}$. Dry papyrus in Singida stored $0.38 \pm$ $0.10 \mathrm{mg} / \mathrm{g}$ of phosphorus as compared with that of Wasare $(0.32 \pm 0.09 \mathrm{mg} / \mathrm{g})$ 
(a) Nitrogen

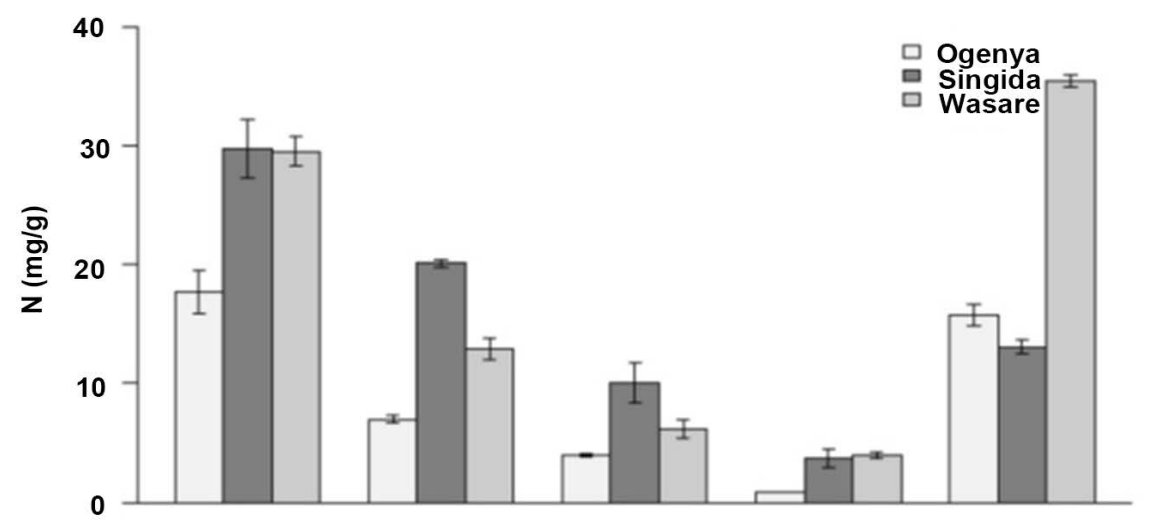

(b) Phosphorus

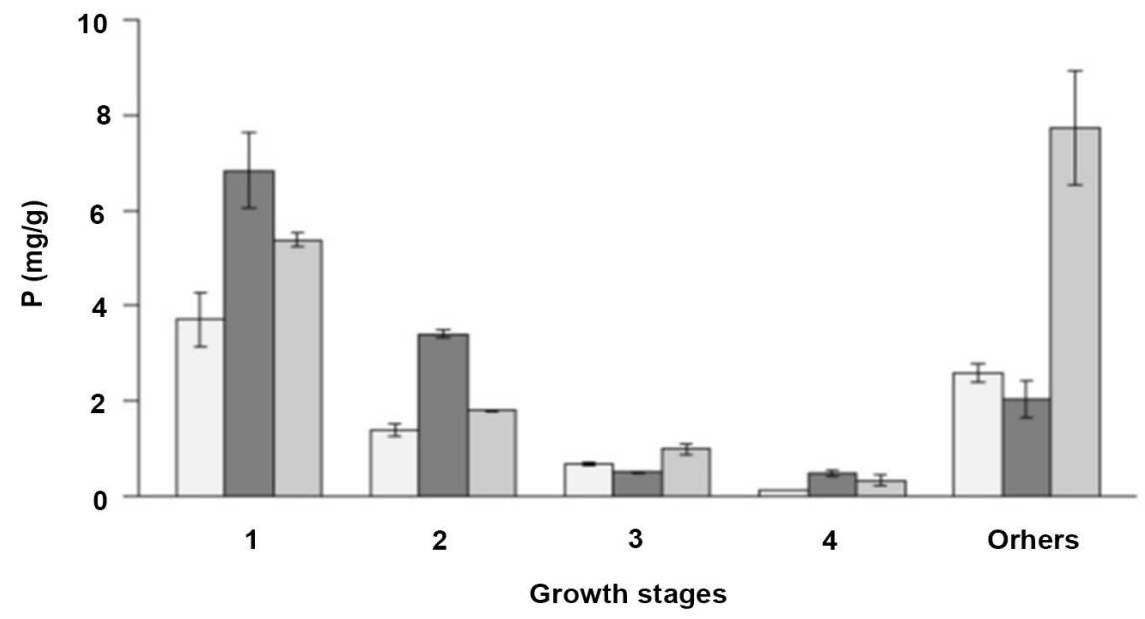

Figure 5. Variation in nutrient content (a) nitrogen and (b) phosphorus in different growth stages of papyrus plant and other associated plants at three study sites of Nyando wetland. Growth stage 1 and 2 formed young stage, while growth stage 3 and 4 formed mature stage for this figure. The arrow bars depict mean \pm SE $(n=10)$.

and Ogenya $(0.12 \pm 0.01 \mathrm{mg} / \mathrm{g})$. One way analysis of variance showed that there was a significant difference in phosphorus stored in plant tissues at different growth stages $(\mathrm{F}=12.28 ; \mathrm{P}<0.001)$ but no difference among transects $(\mathrm{F}=2.43$; $\mathrm{P}>0.05)$.

It is also important to note that other plants associated with papyrus store a significant amount of nutrients as shown in Figure 5(a) and Figure 5(b). This may have implications on the amount of nutrients that is carried to the lake water which contributes to eutrophication. Other plants especially in Wasare which include the Ipomoea aquatic, Polygonum sp. and Cyphostema sp. contain much of the nutrients due to leafy tissues that store more than in the stems, culms or roots.

\subsection{Amount of Nutrients that Harvesting of Papyrus Can Remove from Wetland and Its Implications on Lake Victoria}

Papyrus contribute to the livelihoods of the people living around the wetland 
through provision of biomass used in several purposes. The main purpose is to make mats, fish traps and fencing using mature and senescing growth stages of papyrus. The amount of $\mathrm{N}$ and $\mathrm{P}$ transported away while harvesting papyrus from the wetland in the wet and dry seasons was estimated based on daily harvesting and on the biomass of papyrus growth stages. The removal done daily per person per day was estimated at $105 \mathrm{~m}^{2}$ and $102 \mathrm{~m}^{2}$ in dry and wet seasons respectively in Ogenya. However, in Wasare site an individual harvester removed vegetation on an average area of about $108 \mathrm{~m}^{2}$ and $89 \mathrm{~m}^{2}$ on daily basis in dry and wet seasons respectively.

Through harvesting papyrus and transporting away mature and senescing papyrus plants, it removed $522.9 \mathrm{~kg} \mathrm{~N} / \mathrm{g} \mathrm{DM} /$ ha/day and $97.1 \mathrm{~kg} \mathrm{P} / \mathrm{g} \mathrm{DM} /$ ha/day in Ogenya dry season. This was not different with the wet season which saw removal of $538.2 \mathrm{~kg} \mathrm{~N} / \mathrm{g} \mathrm{DM} / \mathrm{ha} /$ day and $97.0 \mathrm{~kg} \mathrm{P} / \mathrm{g} \mathrm{DM} /$ ha/day. Wasare site showed a higher removal of nutrients with harvesting papyrus in dry season $796.3 \mathrm{~kg} \mathrm{~N} / \mathrm{g} \mathrm{DM} / \mathrm{ha} /$ day and $109.3 \mathrm{~kg} \mathrm{P} / \mathrm{g} \mathrm{DM} /$ ha/day which changed to 746.1 $\mathrm{kg} \mathrm{N} / \mathrm{g} \mathrm{DM} /$ ha/day and $109.2 \mathrm{~kg} \mathrm{P} / \mathrm{g} \mathrm{DM} /$ ha/day in wet season. Overall, papyrus harvesting over the study period removed average nitrogen of $530.6 \mathrm{~kg} \mathrm{~N} / \mathrm{g}$ $\mathrm{DM} / \mathrm{ha}$ /day and $771.2 \mathrm{~kg} \mathrm{~N} / \mathrm{g} \mathrm{DM} / \mathrm{ha} /$ day in Ogenya and Wasare study sites respectively. Phosphorus removed by harvesting papyrus was estimated at $97.1 \mathrm{~kg}$ $\mathrm{P} / \mathrm{g} \mathrm{DM} / \mathrm{ha} /$ day and $109.2 \mathrm{~kg} \mathrm{P} / \mathrm{g} \mathrm{DM} /$ ha/day in Ogenya and Wasare respectively (Table 1).

Table 1 also depicts nutrients that were added to the system as a result of harvesting of papyrus at the study sites. Removal of nutrients in Ogenya did not deplete the reserve of nutrients in the system but this was not the case to Wasare site. There was depletion of both nutrients in the system from the site. This may have been as a result of nutrient additions in Ogenya from the action of wind that moves the water from the lake to the wetland on a daily basis. Wasare site does not interact with the lake but relies on the nutrient that are brought in by flood waters and being used by vegetation as it grows. When the dry season continues, the nutrients are depleted and are not replenished.

\section{Discussion}

\subsection{Seasonal Papyrus Harvesting Patterns}

Papyrus harvesting is one of the main livelihood activity taking place in Nyando floodplain wetland and depended upon by the rural communities to meet their daily needs. This activity is in line with what others have found out to be taking place in most of the wetlands [8] [16] [17] [18]. Clear-cutting of wetland vegetation was done by the harvesters before they select mature and health plants for their use. Furthermore, harvesters do not transport all the harvested material but only mature culms leaving behind the umbels, young and dry culms including other associated plants. The harvested parts may be used for various purposes depending on the needs of the harvesters which can be to meet subsistence and commercial needs of the households in the study sites (Table 2). Harvesting of 
Table 1. Nitrogen and phosphorus added and removed through harvesting of papyrus with associated vegetation from Ogenya and Wasare study sites in Nyando floodplain wetland.

\begin{tabular}{ccccc}
\hline Sites & Nutrients & $\begin{array}{c}\text { Added/remain } \\
(\mathrm{kg} / \mathrm{g} \text { DM/Ha/Day })\end{array}$ & $\begin{array}{c}\text { Removed } \\
(\mathrm{kg} / \mathrm{g} \text { DM/Ha/Day })\end{array}$ & $\begin{array}{c}\text { Balance } \\
(\mathrm{kg} / \mathrm{g} \text { DM/Ha/Day })\end{array}$ \\
\hline \multirow{2}{*}{ Ogenya } & Nitrogen (N) & 786.6 & 530.6 & 256 \\
& Phosphorus (p) & 111.1 & 97.1 & 14 \\
\multirow{2}{*}{ Wasare } & Nitrogen (N) & 412.7 & 771.2 & -358.5 \\
& Phosphorus (P) & 79.7 & 109.2 & -29.5 \\
\hline
\end{tabular}

Table 2. Summary of wetland natural plant products used by people in the Nyando floodplain wetland.

\begin{tabular}{|c|c|c|}
\hline Plant type & Part & Use \\
\hline Cyperus papyrus & Umbel & $\begin{array}{l}\text { Young forage for livestock while mature } \\
\text { is used as a broom }\end{array}$ \\
\hline Cyperus papyrus & Culm & Mats, chairs, artefacts, roofing \\
\hline Cyperus papyrus & Roots/rhizomes & Fuel wood \\
\hline Phragmites sp. & Culms & Fencing, fish traps \\
\hline Phragmites sp. & Leaves & Forage for livestock \\
\hline Vossia cuspidata & Whole & Forage for livestock \\
\hline Cyperus latifolia & Whole & Roofing \\
\hline Solanum sp. & Whole & Wild vegetable \\
\hline Ipomoea aquatica & Whole & Forage \\
\hline Winter berries & Fruit & Wild fruit \\
\hline
\end{tabular}

papyrus biomass in Nyando floodplain was a clear-cutting pattern and is depended upon by the majority of the households to earn income to alleviate poverty. This means all vegetation found was cleared and a selection was made for the right plants to be used for mat-making. This kind of harvesting has an implication on the biomass left to rot in the field and that which is moved to homesteads. This activity is done all year round in all the study sites and it is important since the study site is known to have the highest population density and high poverty levels [19] [20].

Accessibility to the wetland during the dry season made it easier for many people to overexploit these resources to improve their wellbeing. This kind of dry season exploitation of the wetland resources has been established by other researchers [4] [21] [22]. Such over-exploitation may lead to changes in wetland structure, area and reduction of the shoreline vegetation which may negatively influence ecosystem processes and affect the functioning of the wetland [23] [24].

\subsection{C. papyrus L. Growth Stages and Nutrient Storage}

The nutrient concentration stored in plant species tissues differed depending on 
the plant species, the rate of decomposition, growth rate and their ability to oxygenate the rhizosphere, which may influence nutrient cycling [25] [26]. Different growth stages varied in the nutrient concentration in their tissues where young stage papyrus plants had the highest concentration of nutrients than those senescing, and drying plants. Some studies have found similar results where young plants due to their high growth rate will take up more nutrients [13] [27] [28].

The seasonal variations in this study may show the amount of nutrients stored and removed by the wetland which can be linked to other studies. For example, [29] [30] and [31] have reported that removal of $\mathrm{N}$ and P from the wetland vary according to season. However, in this study it shows that nutrients were removed depending on the location of the wetland in relation to the interaction with the lake water. During the study period nutrients were removed during wet seasons more than in dry season in Ogenya site which was at the shore of Lake Victoria. In wet season, the mobility of nutrients to the plant is by moisture which is absent or limiting during the dry season. In Ogenya, the wet season showed removal of nutrients as it is assisted by the rising and falling water levels in the lake which give plants time to take up the nutrients within their tissues. Some studies have found similar work where more nutrients were removed by plants in wet season more than in dry season [27] [32] [33].

Associated plants may play an important role in nutrient storage and cycling in the wetland. There is need to study more of these associated plants which had low biomass but high nutrient content in their tissues. Since it is only mature culms that were being transported away from the wetland, it is likely that most of the vegetation that remained became a source of more nutrients in the wetland that may lead to continuous problem of eutrophication of Lake Victoria. This was seen in the results of Ogenya site which means more nutrients were being added to the system hence the problem of eutrophication will continue to be experienced in Lake Victoria. There is need to integrate the overall wetland plants' role in regulating services and compared with when the wetland is converted for other purposes. This study may lead to understanding important issues for ecologists, land managers, wetland scientists and policy makers into the impacts of papyrus harvesting on nutrient regulation service while meeting the needs of the rural poor communities. Harvesting of papyrus may reduce the problem of eutrophication of the fresh water lake. However, there is need for harvesting strategies to be established while considering the season and location or site in which harvesting can occur for sustainable utilization of papyrus plants.

\section{Conclusions and Recommendations}

Harvesting of papyrus removed more nutrients during the wet season but nutrients were continuously added to the system due to the amount of papyrus and other materials being left to decay in the wetland after harvesting especially in 
the site interacting with the lake water. It is recommended that harvesting of papyrus be done mainly during the rainy season or in permanently flooded areas so as to remove more nutrients. Papyrus harvesting is found to be the best for removing nutrients without altering the wetland ecosystem. However, caution should be taken since these wetlands are sensitive systems that can be altered by climate change experienced globally on climate change. The ecosystem will irreversibly be altered if harvesting pressure coupled with other drivers such as conversion to croplands and livestock grazing is not regulated. This may lead to reduction in economic benefits as well as loss of services such as water purification, soil nutrient cycling, climate stability and others. Due to such risks and the continuing pressure put on these ecosystems, there is need to establish techniques for managing and sustainably using the resources without compromising on other services. Understanding the role of the provisioning services in regulating nutrients may help in decision making process. This will help in managing livelihood activities which benefit people but also maintain the ecosystem functions.

It is recommended that selective harvesting of papyrus culms be practised by the local people so as to have continuous sustainable harvesting throughout the year in both dry and wet seasons. Water level fluctuation in the lake and climate variability in the study area may lead to the wetland becoming a net source rather than being the sink of nutrients including the carbon. Therefore, increasing harvesting activities as a result of hydrological drawdown may lead to more nutrients being removed in the system. However, there is need to understand climate change factors that lead to continuous papyrus growth or failure to grow in the wetland. Harvesting of papyrus may reduce the problem of eutrophication of the fresh water lake.

\section{Acknowledgements}

This project was funded by DGIS through UNESCO-IHE Partnership Research Fund (UPaRF) to "Ecology of Livelihoods in East African Papyrus Swamps" (ECOLIVE) project. This work was conducted in collaboration with the Departments of Water Science and Engineering Technology of UNESCO-IHE Institute for Water Education, Delft, Biological Sciences of Egerton University, Kenya and Victoria Institute for Environment and Development (VIRED International), Kenya. Thanks to research assistant N. Outa for assisting in fieldwork. We appreciate the comments from Prof. J. Kipkemboi and Prof. A. A. van Dam in the first draft of this paper. We appreciate the community members at the study sites for allowing access and participating in the project activities.

\section{Conflicts of Interest}

The authors declare no conflicts of interest regarding the publication of this paper.

\section{References}

[1] MEA (Millennium Ecosystem Assessment) (2005) Ecosystems and $\mathrm{Hu}$ man-Wellbeing: Wetlands and Water Synthesis. World Resources Institute, Wash- 
ington.

[2] TEEB (2010) The Economics of Ecosystems and Biodiversity: Mainstreaming the Economics of Nature: A Synthesis of the Approach, Conclusions and Recommendations of TEEB. United Nations Environment Program, Nairobi.

http://www.teebweb.org

[3] Kansiime, F., Saunders, M. and Loiselle, S. (2007) Functioning and Dynamics of Wetland Vegetation of Lake Victoria: An Overview. Wetlands Ecology and Management, 15, 443-451. https://doi.org/10.1007/s11273-007-9043-9

[4] Kiwango, Y.A. and Wolanski, E. (2008) Papyrus Wetlands, Nutrients Balance, Fisheries Collapse, Food Security, and Lake Victoria Level Decline in 2000-2006. Wetlands Ecology and Management, 16, 89-96.

https://doi.org/10.1007/s11273-007-9072-4

[5] Swallow, M.B., Sang, J.K., Nyabenge, M., Bundotich, D.K., Duraiappah, A.K. and Yatich, T.B. (2009) Trade-Offs, Synergies and Traps among Ecosystem Services in the Lake Victoria Basin of East Africa. Environmental Science and Policy, 12, 504-519. https://doi.org/10.1016/j.envsci.2008.11.003

[6] Van Dam, A.A., Dardona, A., Kelderman, P. and Kansiime, F. (2007) A Simulatio Model for Nitrogen Retention in a Papyrus Wetland near Lake Victoria, Uganda (EA). Wetlands Ecology and Management, 15, 469-480. https://doi.org/10.1007/s11273-007-9047-5

[7] Verhhoeven, J.T.A. and Setter, T.L. (2009) Agricultural Use of Wetlands: Opportunities and Limitations. Annals of Botany, 105, 155-163.

https://doi.org/10.1093/aob/mcp172

[8] Rongoei, P.J.K., Kipkemboi, J., Okeyo-Owuor, J.B. and van Dam, A.A. (2013) Ecosystem Services and Drivers of Change in Nyando Floodplain Wetland, Kenya. African Journal of Environmental Science and Technology, 7, 274-291.

[9] Rongoei, P.J.K., Kipkemboi, J., Kariuki, S.T. and van Dam, A.A. (2014) Effects of Water Depth and Livelihood Activities on Plant Species Composition and Diversity in Nyando Floodplain Wetland, Kenya. Wetlands Ecology and Management, 22, 177-189. https://doi.org/10.1007/s11273-013-9313-7

[10] Kipkemboi, J., van Dam, A.A. and Denny, P. (2006) Biophysical Suitability of Smallholder Integrated Aquaculture-Agriculture Systems (Finger Ponds) in East Africa's Lake Victoria Freshwater Wetlands. International Journal of Ecology and Environmental Sciences, 32, 75-83.

[11] Mwakubo, S.M. and Obare, G.A. (2009) Vulnerability, Livelihood Assets and Institutional Dynamics in the Management of Wetlands in Lake Victoria Watershed Basin. Wetlands Ecology and Management, 17, 613-626. https://doi.org/10.1007/s11273-009-9138-6

[12] World Agroforestry Centre (2006) Improved Land Management in the Lake Victoria Basin: Final Report on the TransVic Project. World Agroforestry Centre, Nairobi.

[13] Muthuri, F.M. and Jones, M.B. (1997) Nutrient Distribution in a Papyrus Swamp: Lake Naivasha, Kenya. Aquatic Botany, 56, 35-50. https://doi.org/10.1016/S0304-3770(96)01093-5

[14] APHA (1998) Standard Methods for the Examination of Water and Wastewater. 20th Edition, American Public Health Association, American Water Works Association and Water Environmental Federation, Washington DC.

[15] R Core Team (2015) R: A Language and Environment for Statistical Computing. R Foundation for Statistical Computing, Vienna. http://www.R-project.org 
[16] Obiero, K.O., Raburu, P.O., Okeyo-Owuor, J.B. and Raburu, E.A. (2012) Community Perceptions on the Impact of the Recession of Lake Victoria Water on Nyando Wetlands. Science Research Essays, 7, 1647-1661. https://doi.org/10.5897/SRE11.324

[17] Terer, T., Triest, L. and Muthama, M.A. (2012) Effects of Harvesting Cyperus papyrus in Undisturbed Wetland, Lake Naivasha, Kenya. Hydrobiologia, 680, 135-148. https://doi.org/10.1007/s10750-011-0910-2

[18] Morrison, E.H.J., Upton, C., Odhiambo-K'Oyooh, K. and Harper, D.M. (2012) Managing the Natural Capital of Papyrus within Riparian Zones of Lake Victoria, Kenya. Hydrobiologia, 692, 5-17. https://doi.org/10.1007/s10750-011-0839-5

[19] Gichuki, J., Guebas, F.D., Mugo, J., Rabuor, C.O., Triest, L. and Dehairs, F. (2001) Species Inventory and the Local Uses of the Plants and Fishes of the Lower Sondu Miriu Wetland of Lake Victoria, Kenya. Hydrobiologia, 458, 99-106. https://doi.org/10.1023/A:1013192330498

[20] World Agroforestry Centre (2012) Lake Victoria Basin. http://www.worldagroforestrycentre.org/newwebsite/sites

[21] Harper, D.M. and Mavuti, K.M. (2004) Lake Naivasha Kenya: Ecohydrology to Guide the Management of a Tropical Protected Area. Ecohydrology \& Hydrobiolo$g y, 4,287-305$.

[22] Osborne, P.L. (2012) Tropical Ecosystems and Ecological Concepts. Cambridge University Press, Cambridge, 349-353. https://doi.org/10.1017/CBO9781139057868

[23] Khisa, P.S., Uhlenbrook, S., van Dam, A.A., Wenninger, J., van Griensven, A. and Abira, M. (2013) Ecohydrological Characterization of the Nyando Wetland, Lake Victoria: A State of System Analysis (SOS) Analysis. African Journal of Environmental Science and Technology, 7, 417-434. https://doi.org/10.5897/AJEST13.1426

[24] Barducci, A., Gizzi, D., Marcoionni, P. and Pippi, I. (2009) Aerospace Wetland Monitoring by Hyperspectral Imaging Sensors: A Case Study in the Coastal Zone of San Rossore Natural Park. Journal of Environmental Management, 90, 2278-2286. https://doi.org/10.1016/j.jenvman.2007.06.033

[25] Rongoei, P.J.K., Kipkemboi, J. and van Dam, A.A. (2015) Decomposition and Nutrient Dynamics of Plant Litter in Nyando Floodplain Wetland, Kenya. Egerton Journal of Science and Technology, 15, 163-186.

[26] Rongoei, P.J.K. and Outa, N.O. (2016) Cyperus papyrus L. Growth Rate and Mortality in Relation to Water Quantity, Quality and Soil Characteristics in Nyando Floodplain Wetland, Kenya. Open Journal of Ecology, 6, 714-735. https://doi.org/10.4236/oje.2016.612065

[27] Kyambadde, J. (2005) Optimizing Processes for Biological Nitrogen Removal in Nakivubo Wetland, Uganda. PhD Thesis, AlbaNova University Centre, Stockholm.

[28] Mburu, N. (2013) Experimental and Modelling Studies of Horizontal Sub-Surface Flow Constructed Wetlands Treating Domestic Wastewater. PhD Thesis, Wageningen and UNESCO-IHE Institute for Water Education, $194 \mathrm{p}$.

[29] Kuschk, P., Wiebner, A., Kappelmeyer, U., Weibbrodt, E., Kastner, M. and Stottmerster, U. (2003) Annual Cycle of Nitrogen Removal by a Pilot-Scale Subsurface Horizontal Flow in a Constructed Wetland under Moderated Climate. Water Research, 37, 4236-4242. https://doi.org/10.1016/S0043-1354(03)00163-5

[30] Vohla, C., Alas, R., Nruk, K., Baatz, S. and Mander, U. (2007) Dynamics of Phosphorus, Nitrogen, and Carbon Removal in a Horizontal Subsurface Flow Constructed Wetland. Science of the Total Environment, 380, 66-74. 
[31] Hes, E.M.A., Niu, R. and van Dam, A.A. (2014) A Simulation Model for Nitrogen Cycling in Natural Rooted Papyrus Wetlands in East Africa. Wetlands Ecology and Management, 22, 157-176. https://doi.org/10.1007/s11273-014-9336-8

[32] Dhote, S. and Dixit, S. (2009) Water Quality Improvement through Macrophytes-A Review. Environmental Monitoring and Assessment, 152, 149-153. https://doi.org/10.1007/s10661-008-0303-9

[33] Sekadende, B.C., Machiwa, F.J. and Mwanuzi, F.F. (2014) Processes Governing the Retention of Phosphorus and Nitrogen in Nyashishi Wetland. Open Journal of Ecology, 4, 124-134. https://doi.org/10.4236/oje.2014.43014 